Medieval Studies, vol. 22, 2018 / Studia z Dziejów Średniowiecza, tom 22, 2018

\author{
Přemysl Bar \\ (Masaryk University, Brno) \\ https://orcid.org/0000-0001-9579-4509
}

\title{
Gdańsk Affairs at the Council of Constance $(1414-1418)^{1}$
}

Keywords: The Concil of Constance, Gdańsk, Teutonic Order, Bridgettine Convent

The Council of Constance (1414-1418), sometimes referred to as the first European congress, is often regarded in historiography as one of the most important events in the Late Middle Ages. In recent years, and thanks to the forthcoming anniversary, research has not only focused on the 'great' religious matters (ending the papal schism and addressing the Wycliffe-Hussite heresy and the reform of the Church) and secular affairs (Sigismund of Luxemburg's European policies and the imperial diet, i.e. Hoftag), but it also looks at more marginal issues. ${ }^{2}$ Thanks to the Council and the arrival of delegations from various corners of the Christian West (as well as a few from the East), Constance became an outstanding meeting place for political negotiations and for establishing commercial and cultural contacts. The different ways in which the Council is perceived is not something confined to contemporary research and is already apparent in the primary sources. ${ }^{3}$

1 The study was conducted as part of the Czech Science Foundation Project "Emperor Sigismund's Party in Hussite Bohemia" (no. GA15-14758S) at the Department of Auxiliary Historical Sciences and Archive Studies, Faculty of Arts, Masaryk University.

2 Cf., e.g. Das Konstanzer Konzil: 1414-1418. Weltereignis des Mittelalters. Essays. Katalog, eds. K.-H. Braun, M. Herweg, H.W. Hubert, J. Schneider, T. Zotz, Darmstadt 2013-2014.

3 The comparison of two primary sources from the Council highlight the different views of the Council: the Council Acts and the Council Chronicle by Ulrich von Richental, cf. Acta concilii Constanciensis I-IV, eds. H. Finke, J. Hollnsteiner, H. Heimpel, 
The affairs of the townspeople of the Hanseatic city of Gdańsk, occupied by the Teutonic Order, also left their mark on the Council of Constance. One Gdańsk townsman was even an official member of the Order's delegation at the Council, although this was not the first delegation of October 1414, but the one held at the start of 1417. However, no more is known about the activities of the Gdańsk councillor, Johann Baysan, in Constance. The representatives of the Prussian knights and the townsmen in the Order's delegation evidently only performed representative roles. Their participation was to provide the impression that the delegation represented the Prussian population as well as the Order (in terms of spiritual bodies). ${ }^{4}$

There were two events that caused tension and conflict in the Hanseatic town which were of greater significance for the Gdańsk townspeople than the participation of their councillor in the Order's delegation. These mainly concerned the consequences of the Gdansk townspeople's uprising against the rule of the Teutonic Knights on 18 June 1416 and the unresolved legal status of the Gdańsk Bridgettine Convent.

\section{The repercussions of the Gdańsk townspeople's uprising (1416) at the Council of Constance}

The immediate causes of the Gdańsk uprising against the Teutonic Order can be traced back to the fiscal policy of the Order's leadership, who lacked the means to compensate Poland and Lithuania for war damages after the so-called Great War (1409-1411). The lowered value

Münster 1896-1928; Chronik des Konstanzer Konzils 1414-1418 von Ulrich Richental, ed. T.M. Buck, Ostfildern 20112; cf. T. Rathmann, Geschehen und Geschichten des Konstanzer Konzils. Chroniken, Briefe, Lieder und Sprüche als Konstituenten eines Ereignisses, München 2000.

4 Cf. the extension of the Brodnica truce of 14 May 1417,: Codex epistolaris saeculi decimi quinti, tomus II, ed. A. Lewicki, Kraków 1891, pp. 84-86, no. 72, where on p. 85 two townspeople are named amongst the membership of the religious delegation: 'Liffhardus Blomental de Thoron et Johannes dictus Baysenn de Danczk, opidani et consules [...];' more on the Gdańsk councillor: J. Zdrenka, Urzędnicy miejscy Gdańska w latach 1342-1792 i 1807-1814, vol. 2, Biogramy, Gdańsk 2008, pp. 15-16 and Poczet sołtysów, burmistrzów, nadburmistrzów, przewodniczacych Miejskiej Rady Narodowej i prezydentów Gdańska od XIII do XXI wieku, ed. B. Możejko, Gdańsk 2015, pp. 50-52; for general information on the delegations at the Council of Constance, see P. Bar, Diplomacie, právo a propaganda v pozdním středověku. Polsko-litevská unie a Řád německých rytíř̉ na kostnickém koncilu (1414-1418), Brno 2017, pp. 42-80. 
of the newly minted coins led to price increases which hit the townspeople the hardest. ${ }^{5}$

In June 1416, Grand Master Michael Küchmeister was staying with the commander of Gdańsk, and it was at that time (on St Corpus Christi on 18 June, which is why this rebellion is called the Fronleichnamsaufstand in German historiography), that an angry crowd attacked the town hall, which they took over and destroyed. At the head of the crowd was the brewer Johann Lupi and the townsman Konrad Bell. The Order's mint was also destroyed along with the house of the mayor, Gert von der Beke, who, as the leaseholder of the Order's mint, was one of the most hated people among the Gdańsk townspeople. The terrified Grand Master fled town, despite the insurgents being unable to translate their surprise control over the town into lasting success. Gdańsk had been successfully isolated by the Order from other Prussian towns, so they could not rely on their solidarity. After a few weeks, the leadership of the Order gradually managed to regain control over the town. The exiled Gdańsk councillors complained about the uprising to the Grand Master and demanded that the rebels be strictly punished.

Under the leadership of the Grand Marshal, the court declared the rebels dangerous disruptors of the social order and with their verdict condemned the leaders, Johann Lupi and Konrad Bell, and other participants in the uprising to death. Ten of the insurgents, including the aforementioned, managed to escape this punishment. A further eighteen people were beheaded, and the court sent forty insurgents into exile. All of the insurgents' property was confiscated. ${ }^{6}$

The repercussions from these dramatic events can be followed at the Council of Constance thanks to messages that were regularly sent to Malbork by the Procurator General acting on Order's behalf in the Roman Curia. Since the thirteenth century, this post had been occupied by a trustworthy cleric who was a member of the Order,

5 On the war 1409-1411, see, e.g. S. Ekdahl, Die Schlacht bei Tannenberg 1410: Quellenkritische Untersuchungen. Band 1, Einführung und Quellenlage, Berlin 1982; S. Jóźwiak, K. Kwiatkowski, A. Szweda, S. Szybkowski, Wojna Polski i Litwy z zakonem krzyżackim w latach 1409-1411, Malbork 2010 and Tannenberg-Grunwald-Žalgiris 1410: Krieg und Frieden im späten Mittelalter, eds. W. Paravicini, R. Petrauskas et al., Wiesbaden 2012. On the economic problems this war caused the Teutonic Order, see M. Biskup, R. Czaja et al., Państwo zakonu krzyżackiego w Prusach. Władza i spoteczeństwo, Warszawa 2009, pp. 342-347.

6 The basic facts mentioned here about the uprising are based on Historia Gdańska, vol. 1, Do roku 1454, ed. E. Cieślak, Gdańsk 1978, pp. 554-561. 
and during the time of the Council of Constance this fell to the priest Peter Wormditt (1403-1419). ${ }^{7}$

It would seem that information about the Gdańsk rebellion and its repercussions soon reached Constance. There is no mention yet of the Gdańsk disturbances in the Procurator's report from mid-July 1416. Peter Wormditt only mentioned that a certain chaplain, Gert von der Beke, probably a relative of the Gdańsk mayor, was present in Constance. ${ }^{8}$ What is certain is that the Order's delegation knew about the Gdańsk uprising by August 1416 at the latest when a letter from the Grand Master of 9 August arrived in Constance for the archbishop of Riga, Johann von Wallenrode. ${ }^{9}$

The reports on the uprising would certainly not have been restricted to the Order's delegation. Paweł Włodkowic (Paulus Wladimiri), an educated lawyer, rector of Krakow University, and a member of the Polish-Lithuanian delegation, devoted one point of indictment to it, in which he wanted to prove the sectarianism and heresy of the Teutonic Order. In the 120th article he wrote that the Order had condemned 14 of Gdańsk's leading townsmen to the cruel punishment of decapitation without a fair trial. In the end, however, these incriminatory articles were not published at the Council. ${ }^{10}$

The Procurator of the Order might have had a certain sympathy towards the critical attitude of the way the Order's leadership had treated the townspeople of Gdańsk. Towards the end of October 1416, a Gdańsk butcher arrived in Constance, who, according to Peter Wormditt, had not yet decided to prosecute the Order; nevertheless, the aggrieved townspeople of Gdańsk would be expected to appear and show their anger at the behaviour of the Order's leadership. ${ }^{11}$

\footnotetext{
J.-E. Beuttel, Der Generalprokurator des Deutschen Ordens an der Römischen Kurie. Amt, Funktionen, personelles Umfeld und Finanzierung, Marburg 1999.

8 Die Berichte der Generalprokuratoren des Deutschen Ordens an der Kurie, Bd. II, Peter von Wormditt (1403-1419) (henceforth: BGDO II), ed. H. Koeppen, Göttingen 1960 , p. 346, no. 168. The editor is in no doubt about the kinship ties between the curate and the Gdańsk mayor.

9 Ibidem, p. 350, no. 170.

10 S.F. Bełch, Paulus Vladimiri and His Doctrine Concerning International Law and Politics, vol. 2, London-The Hague-Paris 1965, p. 978, no. 6 (article 120): 'Item, quod novissime, anno videlicet Domini Millesimo CCCXVI et nunc presenti et de mense Iulii vel quasi eiusdem anni, in oppido Danczk supradicto quattuordecim consules et alios de potioribus dicti oppidi, non convictos, nec confessos de aliquo crimine, iurisque ordine in aliquo non servato, crudeliter decolaverunt, decolarique fecerunt. Itaque fuit et est verum, publicum et notorium.'
}

11 BGDO II, pp. 371-372, no. 186. 
The Procurator's concerns were confirmed a few weeks later when the leaders of the Gdańsk townspeople, Johann Lupi and Konrad Bell, appeared at the Council. In the summer of 1417 both men had travelled to Prussia thanks to the intervention of Peter Wormditt, but the leadership of the Order refused to receive them and so they had returned to Constance.

In two letters from 23 March 1418 the Procurator of the Order added his opinions on these matters for the Grand Master. ${ }^{12}$ He believed that as the supreme government in Prussia, the leadership of the Order should grant both petitioners safe conduct and hear their complaints. In this way the Order could not be criticized for failing to protect its subjects' rights. Johann Lupi was particularly aggrieved that the Grand Master was uninterested in his complaint that his property had been confiscated, which affected his innocent wife and children. Konrad Bell was again to state that he had an alibi for the period when the disturbances began in Gdańsk. His neighbour could apparently confirm that he had been at home sick in bed. He also complained that he had not been given safe passage or his confiscated property back, which should have been returned to him by the commander of Tuchola. In the conclusion to his letter, Wormditt expressed his concern that if the Grand Master did not meet the demands of the townsmen, they would file a public lawsuit against the Order.

Once again the Procurator's presentiment became reality. Johann Lupi and Konrad Bell filed a lawsuit at the imperial court (Reichshofgericht) against two Gdańsk townsmen, the notary of the Grand Master, Hildebrand, and the mayor, Gert von der Beke. The Grand Master sent his lawyer to the court of Sigismund of Luxemburg, who, in the name of the Order, protested against the lawsuit of the Gdańsk townsmen in September 1418. Two arguments were at the centre of his complaint:

- the behaviour of these townsmen towards the Order as rulers was an insult to his royal majesty (crimen lese maiestati);

- the lawsuit at a royal court outside of Prussian territory was a violation of the laws and practices of that country (vor euwirer konigliche gerichte habin lassen laden widder alde des landes zu Prussen gewonheiden, rechte und ussatzunge).

Initially the Grand Master's complaint was not heard, and so on 7 November an imperial anathema (Reichsacht) was announced

12 Ibidem, pp. 468-470, no. 244-245. 
over the accused Gdańsk burgomaster mayor, councillors, and others. ${ }^{13} \mathrm{~A}$ solution was finally found to the complex problem, although we no longer have the details. Midway through 1420, Johann Lupi was once again the owner of his confiscated property on Hundegasse in Gdańsk, and in the so-called Achtbuch, in margine beside the note about the announced Reichsacht was added in Latin absoluti et concordati. ${ }^{14}$

The fact that the Procurator of the Order, Peter Wormditt, stood unequivocally on the side of the rebel townspeople might have been due to a personal dislike of the Gdańsk mayor, Gert von der Beke, who, along with his brother, Hermann von der Beke, was responsible for the Order's financial transactions through the Prussian Hanseatic towns and the Italian banks in Bruges. As a representative of the Order, Hermann von der Beke was responsible for exchanging money for goods brought from Prussia, the deposits with some of the Italian bankers, and the subsequent issue of bills of exchange, which the Procurator of the Order in Constance used to receive money. A complaint repeatedly arises in Peter Wormditt's reports to the Grand Master that the Order's representatives did not deposit the appropriate amounts within the given deadlines in order to avoid delays in paying the money in Constance. Additionally, the Procurator accused both of the von der Beke brothers of lying when they stated that his complaints about their unreliability were completely unfounded.

\section{The controversy over the reform of the Bridgettine Convent in Gdańsk}

As with the uprising by the townspeople, the controversy over the reform of the Bridgettine Convent, founded in Gdańsk at the end of 1390 s, was also of marginal interest in terms of the negotiations at the Council of Constance. Nevertheless, both of these matters were undoubtedly of great importance for the Gdańsk townsmen and the leadership of the Order in Malbork.

The affair surrounding the Gdańsk Bridgettine Convent (the Order of the Most Holy Saviour or in Latin Ordo Sancti Salvatoris)

13 Regesta Imperii XI. Die Urkunden Kaiser Sigmunds (1410-1437), ed. W. Altmann, Innsbruck 1896-1897, p. 259, no. 3692.

${ }_{14}$ Das Achtbuch der Könige Sigmund und Friedrich III. Einführung, Edition und Register, ed. F. Battenberg, Köln-Wien 1986, p. 63. 
at the time of the Council of Constance cannot be understood without recalling its origins. This was because the roots of later controversy lay within the initial stages of its development. ${ }^{15}$

Up until 1392 at the latest, a community of penitents, i.e. former prostitutes (sinners), was to be found at the Church of St Catherine in Gdańsk. Similar communities arose in Europe throughout the thirteenth and fourteenth centuries, which the more prestigious orders became increasingly willing to accept (such as the Clarisses and the Dominicans). In Gdańsk, an order was chosen which had been established in the mid-fourteenth century by the religious visionary and mystic St Bridget of Sweden (died 27 July 1373 in Rome). Her strict order comes from the Benedictine-Cistercian traditions and was confirmed by the pope in 1370 and adapted in 1378 according to the rule of St Augustine. The main foundation in Vadstena in Sweden became the mother convent for all other similar communities in Europe. One of St Bridget's ideas was the establishment of joint convents for sisters and brothers of the order as one administrative unit, headed by an abbess. She would be helped in the administration of the convent by a priest (confessor generalis) from this order. ${ }^{16}$

It is unknown where the initiative came from to accept the rule of St Bridget for the Gdańsk community of penitents. It had great support from the Bishop of Włocławek and the Grand Master of the Teutonic Order, even if they were not directly responsible for it. It can be assumed that there was also some interest in this change on the part of the Gdańsk townspeople and the Gdańsk penitents themselves, although the sources are not too expansive on this. According to a papal mandate from 8 January 1394, the penitents were to accept the rule of St Augustine and it is unclear whether they were also considering the rule of St Bridget. In July of the same year, Grand Master Konrad

15 For more, see R. Stachnik, St. Brigitten Danzig. Geschichte des Brigittinenklosters und der St. Brigittenkirche in Danzig, Danzig 1940, pp. 20-26; for a more accurate interpretation of sources, see T. Nyberg, 'Das Birgittenkloster in Danzig bis Ende 1402,' Zeitschrift für Ostforschung, 40, 1991, pp. 161-225; idem, 'Die Birgittiner von Danzig im baltischen Beziehungssystem des Ordens 1403-1410,' in: Balticum. Studia z dziejów polityki, gospodarki i kultury XII-XVII wieku ofiarowane Marianowi Biskupowi w siedemdziesiata rocznicę urodzin, ed. Z.H. Nowak, Toruń 1992, pp. 241-253; the book by S. Kamińska, Klasztory brygidek w Gdańsku, Elblagu i Lublinie. Założenie $i$ uposażenie, Gdańsk 1970 was not available to me.

16 The issue of a joint convent for women and men, which was controversial within the Order itself, was difficult to realise, cf. H. Cnattingius, Studies in the Order of St. Bridget of Sweden I. The Crisis in the 1420's, Stockholm- Göteborg-Uppsala 1963. 
von Jungingen gave them permission to build a chapel with the patronage of St Mary Magdalena, and their community was subordinated to the parish priest of the town's Church of the Virgin Mary, which was to provide two vicars for their spiritual and liturgical service. However, when on 8 December 1396 the auxiliary bishop of Chełmno, Stephen, accepted their first vows, he did so according to the rule of St Augustine and the constitution of St Bridget (vota professionis secundum regulam sancti Augustini et constituciones sancte Brigitte sumpsimus). ${ }^{17}$ The female penitents, therefore, must have accepted the rule of St Bridget between 1394-1396, but what led them to this step?

According to Tor Nyberg, there were several reasons: the Teutonic Orders' intense efforts to canonize Dorothea of Montau (1347-1394), a mystic and visionary, spiritually linked to St Bridget (in the winter of 1394-1395); the political negotiations between the Grand Master and Queen Margaret of Norway, Sweden and Denmark (1353-1412), and the expected visit of the Grand Master's delegation to Vadstena for the Jubilee celebrations which began in June 1394.

No less important was a visit from a superior of the male community in Vadstena, Brother Magnus Petri (Magnus Peterson of Eka), who was passing through Gdańsk (May-June 1394) on his way to Florence, where he was to establish a Bridgettine convent (il Paradiso)..$^{18}$ It is unknown whether he discovered the plans of the local community of penitents upon his arrival, or if he had been told about them earlier. It can be assumed that the project for a new Bridgettine convent in Florence would have been inspirational for the people in Gdańsk.

The manner in which the first nuns were accepted into the new Bridgettine Convent in Gdańsk (8 December 1396) was more or less dictated by the traditions of the mother community in Vadstena. The candidates had to go through a year's trial period, at the end of which the final vows were taken, followed by entry into the cloister. People who had not taken the final vows were not permitted access to the cloister, and the vows were irrevocable. Only suitable women were selected from the community of penitents (mulieres moribus et regularibus observanciis dispositas). However, unlike

17 See the charter of bishop of Chełmno Stephen on 11 March 1402, in: P. Simson, Geschichte der Stadt Danzig. Band IV, Urkunden bis 1626, Danzig 1918, pp. 76-77, no. 105; cf. T. Nyberg, 'Das Birgittenkloster...,' p. 180.

18 For more on this topic, see H. Cnattingius, Studies in the Order..., pp. 29-39. 
the constitution of St Bridget, where only virgins or widows could be admitted to the convent, here they were exclusively former sinners. It is probable that during this phase the women who aspired to be admitted into the order were divided into three groups (degrees): incipientes, proficientes (a year's preparation), and perfecte (taking vows and entering into the cloister). However, this approach proved to be problematic in practice because the women from the community of penitents who were preparing to take their vows were living with those who had not been selected, and after a certain period of time (usually of three years), they had to leave the community. ${ }^{19}$

This practice was endorsed through the authority of the new bishop of Włocławek, Nicolaus Kurowski (from 16 April 1399). The new nuns were to be selected exclusively from the local community of penitents (quod de cetero ad ordinem professarum nulle omnino mulieres assumantur preterquam peccatrices). The decision concerning the candidates fell to the abbess, presided over by a priest (confessor) and the convent. They even had the right to grant exceptions: nisi forte alique honeste mulieres propter informacionem, sed non ordinis recepcionem ob spem emolumenti monasterio acquirendi sumerentur. Therefore, even women who did not belong amongst the penitents could exceptionally take vows, although economic motivation could not be hidden for this move (entry into the convent in return for a large donation to the convent). The ethical conflict between solidarity with the penitent women and the economic needs of the convent can be easily imagined. ${ }^{20}$

However, this practice was opposed by the rule of St Bridget. A change to this practice was supported in particular by a priest of the Bridgettine Order, Lucas Jacobi (of Spanish origin), whose career within the Order was itself a matter of controversy. ${ }^{21}$

Lucas Jacobi began as a lay brother in Vadstena and soon became a close colleague of Magnus Petri, a superior of the clerical and lay convent in Vadstena. In 1394, Lucas Jacobi accompanied him to Florence (via Gdańsk). Magnus Petri died in Florence (21 March 1396), where a Bridgettine Convent was founded, and he was buried there. According to tradition and recorded in the Vita del beato Manno dell'ordine di Santa Brigid di Svezia, his grave soon became a place

19 See the charter cited in footnote 17; cf. T. Nyberg, 'Das Birgittenkloster...,' pp. 180-183.

20 Ibidem, p. 214.

21 H. Cnattingius, Studies in the Order..., pp. 47-106. 
of reverence and miracles. Brother Magnus apparently loved Lucas Jacobi and wanted him to receive priestly ordination. According to the Vita, Brother Lucas was exceptionally devoted to the strict rules and apparently did not waver from undergoing emasculation. Brother Lucas was to give his first mass in the presence of Magnus Petri. We can trace the origins of this 'reliable' information and the promotion of the reverence for Brother Magnus to Lucas Jacobi, who later actually appeared as a superior at the Florentine convent. ${ }^{22}$

The priest, Lucas Jacobi and Brother Erik Gudmundsson brought news of the death of Brother Magnus to Gdańsk on 27 March 1397 and at the same time taught the nuns the new statutes. They were both required by these nuns to ask the Grand Master of the Teutonic Order for the establishment of a community of priests and laymen in the Gdańsk monastery based on the model of the mother convent in Vadstena. Later, Lucas's career was decisively influenced by the famous conflict between the Abbess of Vadstena, Ingegärd Knutsdotter, and the monks' convent there. The disagreement was caused by a papal bull on 29 March 1399, in which the monks' convent achieved two significant modifications to the constitution of St Bridget. According to this new privilege all the Bridgettine monasteries should have been excluded from the jurisdiction of the local bishop and secondly, the prior of Vadstena as prior generalis was to be placed in a position of supremacy over the whole order. ${ }^{23}$

In reaction to this, Ingegärd Knutsdotter deposed the procurator of the monastery, who had seen nothing amiss in the papal charter, and like the monks from Vadstena convent, agreed with the exemption from the bishop's jurisdiction. In his place she appointed a brother of the Order, Lucas Jacobi (1400), and sent him to Rome to have the papal privilege revoked. Nevertheless, the opposition towards the abbess was so strong that eventually she had to stand down (1403).

In the meantime, Lucas Jacobi had managed to acquire from the papal chancellery several papal bulls which should have strengthened the position of the abbess on the one hand, while simultaneously undermining the power of the confessor general and his group (the

22 G.M. Brocchi, Vite de' santi e beati Fiorentini, parte seconda tomo secondo, Firenze 1761, pp. 178-187; cf. T. Nyberg, 'Das Birgittenkloster..., pp. 190-191. In the eyes of his critics castration and the priesthood were incompatible, cf. H. Cnattingius, Studies in the Order..., p. 103.

${ }_{23}$ H. Cnattingius, Studies in the Order..., pp. 47-50; T. Nyberg, 'Das Birgittenkloster...,' p. 210. 
monks' convent in Vadstena). One of them, for instance, annulled the title of prior generalis and the exemption from the bishop's jurisdiction (Quoniam interdum, 24 April 1401) ${ }^{24}$ Not even the deposition of the abbess could prevent Brother Lucas from setting out on the path he had designated. On 2 June 1401, the pope appointed him Conservator General of the whole Order of St Bridget, which was unusual in its form and essence..$^{25}$ Brother Lucas could use the title, as Cnattingius stated, 'successfully in support of far-reaching intervention in various affairs of the order and to conduct himself as though he had received the position of general of the order. ${ }^{26}$

Although Brother Lucas renounced his conservatorship on 22 April 1403 in Rome as a result of the reconciliation with the representatives of the Vadstena monastery, he actually continued to function as Conservator General of the Order. Among other things, Lucas Jacobi used this position to exercise his right to visit the individual convents. On 14 November 1405 he addressed a letter to the Bridgettine monastery in Gdańsk, in which he appointed as his deputy the priest-monk Johann Resenwold, who came from the male convent in question. In this year, the aforementioned priest was staying in Italy, and, thanks to him, Lucas Jacobi acquired many indulgences for the Gdańsk convent. $^{27}$

${ }_{24}$ Svenskt diplomatarium från och med år 1401. 1. 1401-1407 (henceforth SD), ed. C. Silfverstolpe, Stockholm 1875, pp. 32-33, no. 51; cf. H. Cnattingius, Studies in the Order..., pp. 48-49.

25 SD 1, pp. 42-43, no. 63: 'Bonifacius [IX.] [...] dilecto filio Luce Jacobi, ordinis sancti Augustini, sancti Saluatoris nuncupati, professori, sub regula ac secundum constituciones et instituta sanctarum Marie virginis et Brigide in Wasteno, Lyncopensis dyocesis, degenti [...] [...] te conseruatoribus regule, ordinis, constitucionum et institutorum huiusmodi, hactenus per sedem apostolicam deputatis seu inposterum deputandis, necnon ipsarum numero seu consorcio cum omnibus honoribus, oneribus, priuilegiis et emolumentis ac aliis, quibus dicti conseruatores quomodolibet utuntur, seu alias pociuntur, auctoritate apostolica, tenore presencium, fauorabiliter agregamus, [...] conseruatoribus in presencia(rum) [C: presenti?] existentibus necnon personis huiusmodi ac aliis ad quos pertinet, districte mandamus, quatenus te in conseruatorem regule, ordinis, constitucionum et institutorum predictorum ac ad eius conseruatoratus officium eiusque exercicium recipiant et admittant ac tibi et monicionibus et mandatis tuis, veluti conseruatoribus ipsis prefatis, totaliter pareant et intendant monicionesque et mandata tua huiusmodi efficaciter adimplere procurent, contradictores quoslibet et rebelles per censuram ecclesiasticam appellacione postposita compescendo [...].' For more about the importance of Lucas's appointment as Conservator General, see H. Cnattingius, Studies in the Order..., pp. 50-57.

26 Ibidem, p. 57.

27 Ibidem, pp. 61-62; T. Nyberg, 'Das Birgittiner...,' pp. 241-247. 
Lucas Jacobi's frequent interference in the life of the Gdańsk convent, coupled with the political tension between the Grand Master and Queen Margaret, caused a loosening of the ties with the mother convent in Vadstena, against which Brother Lucas stood in opposition. ${ }^{28}$ As the superior at the Bridgettine Convent in Florence and the Conservator General of the Order, even in later years he acted from a position of authority, which was recognised outside of the order of St Bridget in particular (e.g. at the Roman Curia). For example, in his reports, Peter Wormditt describes him as obirste generalis Lucas von Florencz. ${ }^{29}$

For Brother Lucas and the leadership of the mother convent, the admittance of former sinners among the nuns continued to be a contentious practice. As part of the testimony against Pope John XXIII, the procurator Peter Wormditt testified in Constance that quidam frater Lucas ordinis sancte Brigitte impetravit quandam bullam ab ipso papa Johanne, qualiter concedit monialibus monasterii penitencie in Danczic Wladislaviensis diocesis, que monasteria non recipiunt nisi mulieres peccatrices et communes, quod ipse mulieres debeant exire et redire ad mundum et dimittere habitum et redire ad peccatum. ${ }^{30}$

The original charter of John XXIII must have been held in the Order's archive as the Grand Master sent his copy to the procurator with a question as to whether the papal mandate had been acquired correctly. Peter Wormditt replied in a letter in June 1415 that this was not the case, which was why the document had no legal power. Nevertheless, the procurator handed over his copy to the papal auditor (eynem auditori sacri palacii), who was to revoke it at the first sitting of the Rota. Lucas Jacobi was to appear at this sitting so that his testimony might support his appeal. According to Wormditt, it was only the deposition of the Pope which delayed discussions on this matter. ${ }^{31}$

28 Ibidem, p. 253. However H. Cnattingius, Studies in the Order..., p. 62 argues that "co-operation between monastery and Lucas had never really broken off, and during the Council of Constance and the years immediately following grew positively intimate.'

29 BGDO II, p. 301, no. 144.

30 Ibidem, p. 240, no. 118.

31 Ibidem, p. 249, no. 119: '[...] darczu ich ouch frater Lucam von Florencz, der sy [i. e. the charter of Pope John XXIII] irworben hatte, gebrocht habe, das her synen willen vor dem richter darczu gegeben hot. Unde dese abeseczunge des bobistes hot uns gehindert an der wederruffunge der bulle, wen dy auditores nicht mo gen ir gewalt $\mathrm{u}^{\mathrm{e}}$ ben, is ensy denne, das yn dy gewalt vom concilio werde geben, das noch nicht geschen ist.' 
Although the papal charter to remove all of the former sinners from the Gdańsk convent never came into force, the problem still remained. The community of penitents sent eight articles to Constance, the content of which is no longer extant, along with a question from the Grand Master for Procurator Wormditt asking whether he should administer the community in question. ${ }^{32}$ After learning of its contents, Procurator Wormditt discouraged the Grand Master from taking this step as it would have meant the end of the convent. The representatives of the Order of St Bridget, who were staying at that time in Constance, responded in a similar manner. The aforementioned articles were apparently against the constitution of St Bridget and their application would have caused untold damage to the Gdańsk convent.

The deputies of the Vadstena monastery as well as the Order of St Bridget were represented at the Council by the priest, Tore Andersson, and one lay brother, who led the negotiations with Procurator Wormditt. ${ }^{33}$ He asked them why they were against revoking the papal bull when it would be so damaging to the Gdańsk community of penitents. Although their position was not as radical as Lucas Jacobi's, who wanted to simply cleanse the Bridgettine Convent of all former sinners, they still had two objections. There were no virgins in the Gdańsk convent to choose an abbess from, and they did not live in a cloister as they should. Some of them would even leave the convent grounds. ${ }^{34}$

Tore Andersson (der oberste procurator von Watsten) should have declared that he spent more than a year in Gdańsk, where apparently he tried to convince the nuns of the benefits of having virgins and devout widows in their convent. Peter Wormditt advised the Grand Master not to bother the Gdańsk Bridgets too much, as over the past 15 years they had not enjoyed much peace, particularly from Lucas Jacobi. Maintaining the Bridgettine nuns was in itself incredibly difficult. Peter Wormditt apparently wrote that if the penitents and nuns asked the Grand Master to accept virgins and windows to the cloister and the school (?) so that they would form one-third

32 Cf. the report by Procurator Peter Wormditt to the Grand Master from 28 September 1415, in: BGDO II, pp. 259-262, no. 124.

33 T. Nyberg, Birgittinische Klostergründungen des Mittelalters, Leiden 1965, pp. 82-89 deals with the issues concerning the Order of St Bridget at the Council of Constance.

34 BGDO II, pp. 260-261, no. 124: '[representatives of Vadstena monastery had] keyne sache anders wider sie, denne das sie nicht juncfrauwen mit in im closter hetten, us den sie eyn eptissynnen und priorynnen mogen kysen, und das sie nicht also vorslossen sein, als sie sulden, und beywilen eczliche wider usgeczogen weren.' 
of the community, then Cardinal Oddo Colonna would confirm the cancellation of the papal bull with his own seal, and the representatives of the convent in Vadstena would gladly pursue this. ${ }^{35}$

After meeting with representatives from the Vadstena convent, Procurator Wormditt wrote the following to the community of penitents in Gdańsk: if they want to remain within the rule of St Bridget, they have to accept virgins among them so that an abbess might be chosen. The procurator imagined that six or seven women would suffice, in order to prevent the penitents from feeling that they were in a significant minority. However, if the former sinners did not want virgins among them, then they would have to accept an order whose statute did not require an abbess.

At the end of his letter, Peter Wormditt asked the Grand Master for support for the Gdańsk community of penitents. Their place within town society was irreplaceable, particularly when in previous years they had been upset by Lucas Jacobi and Hannus Seteler, ${ }^{36}$ who had tried to break up this community.

The Constance negotiations evidently had a specific impact because some of the proposals in the procurator's reports appeared in reformist articles which were submitted by Bishop Johann of Pomesania on 19 August 1416. According to him, the Gdańsk convent was to house 20 of the lowest penitents (nedirste busserynnen or incipientes), 12 penitents in the cloister (proficientes), and 12 nuns who had taken eternal vows (perfecte). The bishop demanded that these 20 nedirste busserynnen were not to leave the convent grounds. Alms were to be collected for them by other people with better reputations (die bestendig und eyns guten geruchtes weren). The bishop's reform proposal coincided with the interests of the Teutonic Order, which was given the right to appoint a visitor to the Gdańsk convent inspector. At the same time, emphasis was placed on strong ties between the Gdańsk convent and the mother community in Vadstena, which impinged on the jurisdiction of the Bishop of Włocławek.

35 Ibidem, pp. 261-262, no. 124: '[...] undir den vorslossen und in der schule das dritte teil juncfrauwen und witewen [...] würde der Kardinal de Columpna als eyn richter den Widerruf myt synem angehangenden ingesigel bestätigt haben, und die von Watsteen hetten in gerne lassen gnugen, als sie noch thun.'

36 He could be identified with Johann Seteler, the mayor of the Young Town Gdańsk in 1405-1415, or his son of the same name, see ibidem, pp. 262, no. 124, footnote 18. 


\section{Summary}

At first sight it might seem that the Procurator of the Teutonic Order, Peter Wormditt, had represented the interests of the Gdańsk townspeople more than the Grand Master and the Order's leadership at Constance. In reality, what came first was the good name of the Order in the eyes of the European public. The leading representatives of the Order did not always understand, from a procurator's perspective, the consequences and wider ramifications of their decisions concerning their subjects. Therefore, paradoxically, Wormditt's criticisms of the Grand Master were motivated by the wish to spread and preserve the good name of the Teutonic Knights.

Naturally, the Gdańsk affairs were not of such significance that they were part of the agenda of the main Council meetings. On the other hand, the Council of Constance gradually grew in importance as the town drew in representatives from nearly all of the Church hierarchy, European universities, and delegations from rulers, princes, and towns. The presence of the Roman king and his court also attracted many people from across Europe who came hoping to settle public or even private affairs. Gdańsk and its townspeople contributed, albeit slightly, to the fact that the description of the Council of Constance as a European congress, or a Medieval global event, would appear to be entirely justified. 